\title{
POTENSI BAKTERI INDIGEN DALAM MENDEGRADASI LIMBAH CAIR PABRIK KULIT SECARA IN VITRO
}

\author{
The Potential of Indigen Bacteria to Degrade Tanning Waste \\ Hasminar Rachman Fidiastuti ${ }^{1}$, Endang Suarsini ${ }^{2}$ \\ ${ }^{1)}$ Fakultas Ilmu Kesehatan, Universitas Tribhuwana Tunggadewi \\ Jalan Telaga Warna, Malang 65144 \\ 2)Universitas Negeri Malang \\ indo.hasminar@gmail.com
}

\begin{abstract}
Biodegradation can be one of the wastewater treatment technologies are safe and environmentally. In nature, bacteria potentially in the process of biodegradation can be isolated from the waste itself. The bacteria is called as indigen bacteria. "Badheg" is one of the river in the Malang which one of the polluted rivers leather factory waste. Water quality test results of the samples indicate conditions higher than water quality standards, which amounted to $400 \mathrm{ppm}$ TSS, BOD of $331 \mathrm{mg} / \mathrm{L}, \mathrm{COD}$ of $544 \mathrm{mg} / \mathrm{L}, \mathrm{DO}$ of $3.6 \mathrm{mg} / \mathrm{L}$ and the fat content of $280 \mathrm{mg} / \mathrm{L}$. Waste leather factory has a characteristic pungent, black color, and contain large amounts of fat. Fat is known as one of the organic materials that are difficult to be degraded naturally. Biodegradation activities carried out by way of introducing bacteria indigen who have been selected from the isolation process and has the potential to degrade the highest, then cultured and inoculated back in water samples, so that the transformation process will take more optimal. The results of biodegradation in vitro using indigen bacteria, showing a change of 293ppm TSS, BOD $117 \mathrm{mg} / \mathrm{L}, C O D$ of $165 \mathrm{mg} / \mathrm{L}, \mathrm{DO}$ at $19 \mathrm{mg} / \mathrm{L}$ and the fat content of $0.02 \mathrm{mg} / \mathrm{L}$. Biodegradation is an effective way to degrade organic matter, especially the fat content.
\end{abstract}

Keywords:Biodegradation, In vitro, Tanning pollutants, Indigen bacteria

\begin{abstract}
Abstrak-Biodegradasi dapat menjadi salah satu teknologi pengolahan air limbah yang aman dan berwawasan lingkungan. Secara alamiah, bakteri yang berpotensi dalam proses biodegradasi dapat diisolasi dari limbah itu sendiri. Bakteri inilah yang disebut sebagai bakteri indigen. Sungai Badheg di kota Malang merupakan salah satu sungai yang tercemar limbah pabrik kulit. Hasil uji kualitas air dari sampel menunjukkan kondisi yang tidak memenuhi baku mutu air, yaitu TSS sebesar 400 ppm, BOD sebesar $331 \mathrm{mg} / \mathrm{L}$, COD sebesar $544 \mathrm{mg} / \mathrm{L}$, DO sebesar 3,6 mg/L dan kadar lemak sebesar 280 $\mathrm{mg} / \mathrm{L}$. Limbah pabrik kulit memiliki karakteristik yang berbau tajam, berwarna hitam pekat, dan mengandung lemak dalam jumlah yang besar. Lemak diketahui sebagai salah satu bahan organik yang sulit untuk diuraikan secara alamiah. Peran bakteri indigen akan mengoptimalkan proses biodegradasi lemak yang terjadi. Kegiatan biodegradasi dilakukan dengan cara mengintroduksi bakteri indigen yang telah diseleksi dari proses isolasi dan memiliki potensi pendegradasi paling tinggi, kemudian dikultur dan diinokulasikan kembali pada sampel air, sehingga proses transformasi akan berlangsung lebih optimal. Hasil biodegradasi secara in vitro menggunakan bakteri indigen, menunjukkan perubahan TSS sebesar 293ppm, BOD 117 mg/L, COD sebesar 165 mg/L, DO sebesar 19 mg/L dan kadar lemak sebesar $0,02 \mathrm{mg} / \mathrm{L}$. Biodegradasi merupakan cara yang efektif dalam mendegradasi bahan organik, terutama kadar lemak.
\end{abstract}

Kata kunci: Biodegradasi, In vitro, Limbah pabrik kulit, Bakteri indigen

\section{PENDAHULUAN}

Era perkembangan Biologi saat ini telah memasuki tahap baru, yang kecenderungannya secara global mengalami transisi dari pemanfaatan teknologi secara fisik dan kimia, berganti menjadi pemanfaatan yang mengedepankan era Biologi. Konsep yang ingin dicapai manusia sejalan dengan hal tersebut adalah kemajuan teknologi dan perkembangan informasi yang seirama dengan pemahaman terhadap lingkungan serta pengelolaan lingkungan, dan menunjukkan kecenderungan perubahan 
dunia dimana "zaman Biologi telah menggantikan zaman Fisika" (Naisbitt \& Aburdene, 1990). Hal ini muncul karena banyak produk hasil manusia yang justru merusak keseimbangan alam bahkan membahayakan manusia itu sendiri.

Salah satu masalah yang dihadapi manusia adalah mencari solusi atas pencemaran yang terjadi. Pencemaran berkaitan erat dengan limbah yang dihasilkan dari aktivitas manusia. Permasalahan limbah terjadi karena tidak seimbangnya produksi limbah yang dihasilkan dengan aktivitas pengolahan limbah, serta menurunnya daya dukung lingkungan sebagai tempat pembuangan limbah.

Salah satu lokasi di kota Malang yang menghasilkan limbah dan merusak ekosistem perairan adalah sungai Badeg yang berlokasi di Jalan Kolonel Sugiono Gang 8. Sungai Badegdialiri oleh limbah cair dari 2 pabrik besar pengolahan kulit yaitu PT Usaha Loka dan PT Kasin di Jalan Susanto. Hasil buangan limbah PT Usaha Loka dan PT Kasin ini mengalirkan limbah yang bermuara ke Sungai Badeg. Selain pemukiman warga, sungai Badeg juga mengalir melewati sekolah SD Ciptomulyo 2 dan SMP PGRI 6 Malang. Aktivitas kedua pabrik ini menghasilkan limbah cair berwarna abu-abu, keunguan, bahkan hitam dan berbau busuk serta menyengat. Pencemaran menyebabkan penurunan kualitas air dan gangguan terhadap biota di perairan sekitar sungai.

Pengambilan sampel penelitian yang dilakukan oleh peneliti di tiga titik pada aliran sungai Badeg, menunjukkan bahwa air yang mengalir di sungai tersebut memiliki hasil perbandingankadar BOD (Biochemical Oxygen Demand), COD (Chemichal Oxygen Demand), TSS (Total Suspended Solid), DO (Dissolved Oxygen), dan lemak (tampak pada Tabel 1) yang berada di atas batas ambang yang telah ditentukan dalam baku mutu air sesuai Peraturan Pemerintah No 82 Tahun 2001 untuk kondisi perairan kelas II, yaitu sebagai air sungai, sehingga sangat tepat jika dilakukan biodegradasi untuk memperbaiki kondisi perairan.

Tabel 1.Perbandingan Parameter Kimia Organik dan Anorganik Air Sungai Badeg dengan Kriteria Mutu Air Kelas II

\begin{tabular}{|c|c|c|c|}
\hline Parameter & Satuan & Sungai Badeg & Mutu Air Kelas II \\
\hline \multicolumn{4}{|l|}{ Fisika } \\
\hline TSS & Ppm & 400 & 50 \\
\hline \multicolumn{4}{|l|}{ Kimia Anorganik } \\
\hline BOD & $\mathrm{mg} / \mathrm{L}$ & 331 & 3 \\
\hline COD & $\mathrm{mg} / \mathrm{L}$ & 544 & 25 \\
\hline DO & $\mathrm{mg} / \mathrm{L}$ & 3.577 & 4 \\
\hline \multicolumn{4}{|l|}{ Kimia Organik } \\
\hline Lemak \& Minyak & $\mathrm{mg} / \mathrm{L}$ & 280 & 1 \\
\hline
\end{tabular}


Salahsatu teknologipengolahan airlimbah yang aman dan berwawasanlingkungan adalah menggunakan bakteri yang berpotensi sebagai pengurai dalam proses biodegradasi.Secara alamiah untuk memperoleh bakteri yang berpotensi sebagai pengurai dapat dilakukan dengan mengisolasi limbah itu sendiri (bakteri indigen), kemudian dikultur secara murni di dalam laboratorium secara in vitro. Pemanfaatan konsorsia bakteri yang berpotensi akan diperbanyak di laboratorium untuk selanjutnya dipakai sebagai starter dalam pengolahan limbah. Transformasi dilakukan oleh mikroorganisme, khususnya bakteri pendegradasi melalui proses metabolisme dengan cara menghasilkan enzim. Optimalisasi kondisi lingkungan dilakukan agar aktivitas metabolisme mikroba dapat terselenggara dengan baik. Biodegradasi didefinisikan sebagai suatu proses oksidasi senyawa organik oleh mikroba karena adanya proses metabolisme zat organik melalui enzim untuk menghasilkan karbon dioksida, air dan energi yang akan digunakan dalam sintesis, mortalitas dan respirasi (Shovitri, dkk. 2012).

Alexander (1999) mendefinisikan biodegradasi sebagai reduksi yang dikatalisasi secara biologis dalam sebuah kompleksitas bahan kimia. Biodegradasi sebagai reduksi berarti terjadi proses transformasi dari bahan pencemar dengan molekul yang kompleks menjadi lebih sederhana melalui sebuah proses biologis akibat aktivitas mikroorganisme, melalui enzim yang dihasilkannya. Proses biologis ini merupakan sebuah proses yang bersifat alamiah, dinamis dan kontinyu selama faktor-faktor yang berhubungan dengan kebutuhan mikroorganisme dapat terpenuhi.

Biodegradasi dan pengolahan secara biologi memiliki beberapa keunggulan, diantaranya adalah sebagai berikut (Tong
Yu et al.,).

Prosesnya merupakan proses yang bersifat ekonomis dan efektif

Mikroorganisme sudah tersedia dan dalam keadaan yang siap untuk digunakan (indigen)

Toksisitas pada perairan dapat dikurangi

\section{METODE PENELITIAN}

Kegiatan penelitian dilakukan dalam 8 tahapan, meliputi 1) Penentuan lokasi dan tehnik pengambilan sampel air, 2) Pembuatan medium, 3) Propagasi bakteri indigen, 4)Tahap penapisan bakteri pendegradasi lemak, 5) Pengukuran indeks hidrolisis, 6) Inventarisasi data dan uji statistik, 7) Identifikasi dan pemilihan bakteri yang paling berpotensi dalam menghidrolisis lemak, dan 8) Pengujian biodegradasi secara in vitro.

\section{Subjek Penelitian}

Sampel penelitian berupa limbah cair industri penyamakan kulit diambil dari aliran sungai badeg pada jam-jam tertentu (jam dimana limbah dibuang langsung ke badan air, yaitu jam 17.00 WIB, jam 21.00 WIB dan jam 03.00 WIB). Sebelum perlakuan, limbah disterilkan terlebih dahulu.

\section{Alat dan Bahan (Jika Perlu)}

Pada penelitian ini menggunakan bahan-bahan meliputi: Medium Busnell Hass, sampel limbah cair pabrik kulit, olive oil 1\%, Nutrien Agar (NA), Nutrien Cair (NC), Alkohol 70\% dan $95 \%$, aquades steril, pepton, beef extract, isolat bakteri indigen, air kran, lisol, kertas penghisap, sabun cuci, larutan Amonium Oksalat Kristal Violet, larutan Safranin, larutan Iodium, larutan Tembaga Sulfat $\left(\mathrm{CuSO}_{4} \mathrm{H}_{2} \mathrm{O}\right)$, larutan hijau malakit, etanol, aluminium foil, kertas tisu, kapas dan kasa. 


\section{Metode dan Desain Penelitian}

Metode dalam penelitian biodegradasisecarainvitromerupakan eksperimen laboratorik dengan menggunakan Rancangan Acak Kelompok (RAK) dan disusun secara faktorial. Melibatkan 2 faktor yaitu variasi inokulan dan waktu inkubasi.

Faktor variasi inokulan terdiri atas 4 kombinasi yaitu inokulan $\mathrm{A}$, B, C, dan $\mathrm{A}+\mathrm{B}+\mathrm{C}$. Sedangkan faktor waktu inkubasi meliputi pengamatan awal percobaan, hari pertama, hari kedua, hari ketiga dan hari keempat.

Variabel yang terdapat dalam penelitian ini adalah sebagai berikut:

a. Bebas, meliputi variasi inokulan, waktu inkubasi, dan interaksi antara variasi inokulan dengan waktu inkubasi

b. Terikat meliputi kualitas limbah yang diukur berdasarkan parameter BOD, COD, DO, TSS dan kadar lemak.

c. Kontrol meliputi suhu, $\mathrm{pH}$ dan aerasi

Adapun tehnik pengukuran kualitas limbah adalah sebagai berikut:

a. Kadar BOD diukur dengan metode analisis $5^{\text {th }}$ day incubation

b. Kadar COD diukur dengan metode analisis Dichromate Oxidation

c. Kadar DO diukur dengan metode analisis Dissolved Oxygen Before

d. Kadar TSS diukur dengan metode analisis Gravimetri.

e. Kadar lemak diukur dengan metode analisis Direct Acid Hydrolysis.

\section{Teknik Pengumpulan Data}

Sampel limbah yang sudah disterilkan kemudian dipropagasi dalam media Busnell Hass yang diperkaya dengan olive oil $1 \%$ selama 14 hari yang bertujuan untuk memperbanyak jumlah sel bakteri. Sampel limbah diinokulasikan pada medium NA dan diinkubasi dengan posisi terbalik pada suhu $37^{\circ} \mathrm{C}$ selama $1 \times 24$ jam. Biakan murni bakteri hasil isolasi yang didapat merupakan starter. Starter kemudian diinokulasikan ke dalam botol yang berisi limbah dengan perbandingan volume starter: volume limbah $=1: 10$. Isolat bakteri indigen diinokulasikan secara aseptik dengan jarum inokulasi berkolong pada medium Nutrien Agar Cair.

\section{Analisis dan Interpretasi Data}

Data yang diperoleh adalah berupa parameter yang digunakan dalam analisis air limbah, yaitu kadar lemak, TSS, BOD, COD, dan DO. Data yang diperoleh dianalisis dengan menggunakan Analisis Varian Tunggal dan uji lanjut Duncan $5 \%$. Potensi keefektifan setiap isolat bakteri dalam mendegradasi limbah dihitung berdasarkan rerata efisiensi optimasi, dengan rumus sebagai berikut:

$$
\% \text { Degradasi }=\text { x 100\% }
$$

\section{HASIL DAN PEMBAHASAN}

1. Isolat Bakteri yang Terisolasi dari Limbah Cair Pabrik Kulit

Hasil penelitian menunjukkan bahwa ditemukan 9 mikroorganisme, dan 3 diantaranya merupakan khamir, sehingga tidak digunakan dalam penelitian ini, sehingga terdapat 6 isolat bakteri yang berpotensi dalam mendegradasikan lemak pada limbah cair. Hasil degradasi lemak dalam kurun waktu 1×24 jam terlihat pada Grafik 1. 


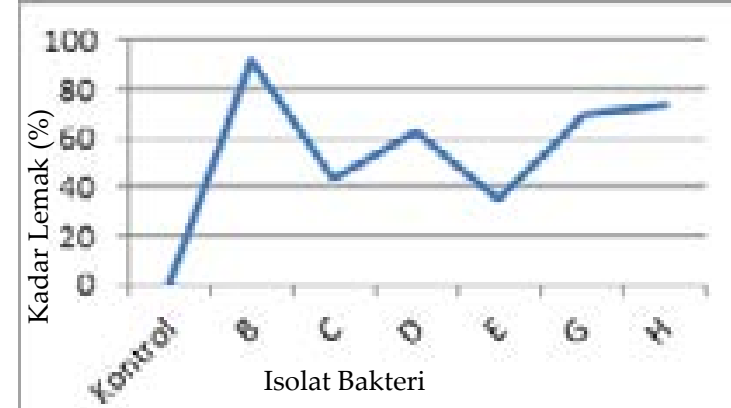

Grafik 1. Efisiensi Kemampuan Isolat Bakteri yang Ditemukan dalam Mendegradasi Lemak (waktu 1x24 jam)

Dari keenam isolat bakteri yang ditemukan tersebut, dipilih 3 isolat yang memiliki kemampuan degradasi lemak tertinggi. Hasil uji Anava dilanjutkan uji Duncan menunjukkan bahwa isolat $B$, G dan $\mathrm{H}$ memiliki kemampuan degradasi tertinggi sehingga ketiganya digunakan sebagai isolat uji untuk tahap biodegradasi secara in vitro. Isolat bakteri terpilih, teridentifikasi sebagai spesies Staphyllococcus aureus (Isolat B), Pseudomonas pseudomallei (Isolat G) dan Actinobacillus sp. (Isolat $\mathrm{H})$.

Spesies Staphyllococcus aureus memiliki rerata efisiensi optimasi penurunan kadar lemak sebesar 91,29\%, spesies Pseudomonas pseudomallei memiliki rerata efisiensi optimasi penurunan kadar lemak sebesar $69,47 \%$ dan spesies Actinobacillus sp. memiliki rerata efisiensi penurunan kadar lemak sebesar $73,85 \%$ dalam kurun waktu 1x24 jam.

Terdapat beberapa faktor yang berpengaruh terhadap hasil isolasi bakteri, salah satu diantaranya adalah komponen penyusun limbah. Limbah cair tersusun atas komponen fisika, kimia, dan biologi sehingga ketiga komponen inilah yang akan mempengaruhi komposisi limbah cair (Atlas, 1993). Droste (1997) menyebutkan bahwa pada limbah penyamakan kulit, yang dominan adalah lemak. Karakteristik limbah pabrik kulit yang berwarna keruh bahkan sampai berwarna kehitaman dan berbau busuk adalah disebabkan karena adanya sisa-sisa daging dan darah, mengandung bubur kapur, bulu halus, protein terlarut dalam kadar yang cukup tinggi, sisa garam serta asam, dan mengandung bahan penyamak yaitu krom serta sisa-sisa zat warna.

2. Kemampuan Ketiga Isolat yang Berpotensi terhadap Proses Biodegradasi secara In vitro pada Limbah Cair Pabrik Kulit

Indikator yang digunakan dalam penentuan keberhasilan proses biodegradasi dalam limbah cair pabrik kulit adalah penurunan kadar lemak, penurunan kadar BOD, COD, dan TSS, serta kenaikan kadar DO. Berikut adalah hasil efisiensi degradasi lemak oleh konsorsium bakteri indigen yang tersaji dalam Grafik 2 sebagai berikut.

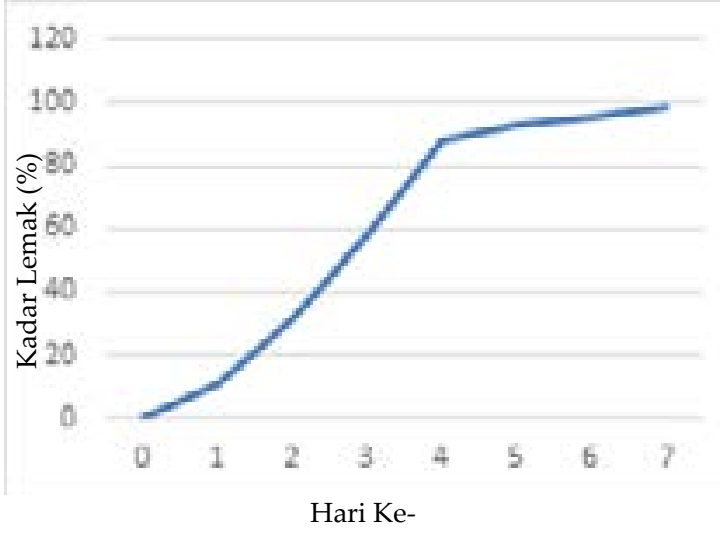

Grafik 2. Efisiensi Degradasi Lemak (\%) dari hari ke 0 sampai hari ketujuh oleh Konsorsium Bakteri

Efisiensi degradasi lemak oleh konsorsium bakteri indigen berpotensi diketahui memiliki rerata 
keefektifan sebesar 98,42\%. Sehingga kadar lemak dalam sampel air yang tadinya sebesar $280 \mathrm{mg} / \mathrm{L}$ turun menjadi $0.0226 \mathrm{mg} / \mathrm{L}$ dalam waktu tujuh hari.

Keberhasilan degradasi bahan organik dapat juga dilihat dari penurunan kadar BOD, COD dan TSS serta kenaikan kadar DO. BOD digunakan untuk mengukur banyaknya oksigen yang dikonsumsi oleh mikroba dalam proses penguraian bahan organik yang terlarut dalam limbah cair. Sebuah angka BOD yang tinggi menunjukkan kelimpahan substrat organik yang dapat digunakan oleh mikroorganisme aerobik. Ketika kandungan BOD tinggi, menunjukkan bahwa mikroorganisme sering menggunakan banyak oksigen terlarut untuk degradasi bahan organik, hal ini akan menciptakan kondisi delesi oksigen (penurunan kadar DO) dan menyebabkan kematian organisme yang lebih tinggi, seperti ikan, yang membutuhkan $\mathrm{O}_{2}$ untuk bertahan hidup (Atlas et al., 1998).

Biodegradasi

akan

memaksimalkan proses penguraian zat organik sehingga mengakibatkan penurunan kadar BOD, dikarenakan degradasi lemak terus berjalan, sehingga kadar lemak akan semakin menurun. Dengan menurunnya kadar lemak, maka jumlah oksigen yang dikonsumsi mikroba dalam proses penguraian akan semakin menurun. Penentuan parameter keberhasilan biodegradasi disajikan dalam Tabel 2.

Tabel 2. Parameter Keberhasilan Biodegradasi

\begin{tabular}{ccccc}
\hline Parameter & Satuan & $\begin{array}{c}\text { Sampel } \\
\text { Air Awal }\end{array}$ & $\begin{array}{c}\text { Biodegradasi } \\
\text { In vitro }\end{array}$ & $\begin{array}{c}\text { Baku Mutu Air Kelas } \\
\text { II }\end{array}$ \\
\hline Fisika & & & & 50 \\
TSS & Ppm & 400 & 293.333 & \\
$\begin{array}{c}\text { Kimia } \\
\text { Anorganik }\end{array}$ & & & & 3 \\
BOD & $\mathrm{mg} / \mathrm{L}$ & 331 & 117.344 & 25 \\
COD & $\mathrm{mg} / \mathrm{L}$ & 544 & 165.333 & 4 \\
DO & $\mathrm{mg} / \mathrm{L}$ & 3.577 & 19 & \\
$\begin{array}{c}\text { Kimia Or- } \\
\text { ganik }\end{array}$ & & & & 1 \\
Lemak & $\mathrm{mg} / \mathrm{L}$ & 280 & 0.0226 & \\
\hline
\end{tabular}

Efektifitas penguraian bahan organik dengan penambahan inokulum bakteri menjadi lebih tinggi jika dibandingkan dengan penguraian bahanorganikyangtanpapenambahan inokulum. Mikroorganisme dapat mengkonsumsi polutan organik dan mengubah polutan organik tersebut menjadi karbondioksida, air dan energi untuk pertumbuhan dan reproduksinya.Penambahan inokulum kultur campuran bakteri akan merangsang proses penguraian terjadi lebih cepat dibandingkan 
dengan yang tidak ditambahkan inokulum bakteri, karena waktu yang dibutuhkan untuk menguraikan lebih lama dibandingkan yang ditambahkan inokulum. Hal ini sejalan dengan hasil penelitian, bahwa pada perlakuan kontrol, yaitu perlakuan yang tidak ditambahkan dengan kultur bakteri menunjukan angka degradasi yang sangat sedikit.

Lemak merupakan salah satu contoh bahan organik. Bahan organik secara alamiah lebih mudah terurai daripada bahan anorganik. Pertumbuhan bakteri Staphyllococcus aureus, Pseudomonas pseudomallei dan Actinobacillus sp.akan menghasilkan enzim lipolitik sehingga dapat mendegradasi lemak menjadi substrat yang lebih sederhana. Substrat ini terhidrolisis menjadi asam piruvat. Selanjutnya, jika kondisi lingkungan mengandung cukup oksigen, melalui mobilisasi asetil-KoA akan masuk dalam lingkaran asam trikarboksilat (Siklus Krebs) yang pada akhirnya akan dibebaskan menjadi $\mathrm{CO}_{2}$ dan $\mathrm{H}_{2} \mathrm{O}$.

Pada waktu bakteri tumbuh dan berkembang dalam limbah tersebut, karbon akan digunakan untuk menyusun bahan sel penyusun mikroba dengan cara membebaskan karbondioksida dan bahanbahan lain yang mudah menguap. Dalam proses biodegradasi yang berlangsung tersebut, maka mikroba juga akan mengasimilasi nitrogen, fosfor, kalium dan belerang yang terikat dalam protoplasma sel. Hal ini sesuai dengantujuan utama penanganan limbah secara biologi adalah untuk mendegradasi dengan cara mengoksidasi limbah organik, sehingga senyawa-senyawa kompleks dapat terurai menjadi senyawa- senyawa yang lebih sederhana dan lebih mudah larut, disamping itu juga dapat dimanfaatkan sebagai nutrisi oleh bakteri indigen.

Lemak merupakan salah satu contoh bahan organik. Bahan organik secara alamiah akan mudah terurai. Pertumbuhan bakteri Staphyllococcus aureus, Pseudomonas pseudomallei dan Actinobacillus sp.akan menghasilkan enzim lipolitik sehingga dapat mendegradasi lemak menjadi substrat yang lebih sederhana. Substrat ini terhidrolisis menjadi asam piruvat. Selanjutnya, jika kondisi lingkungan mengandung cukup oksigen, melalui mobilisasi asetil-KoA akan masuk dalam lingkaran asam trikarboksilat (Siklus Krebs) yang pada akhirnya akan dibebaskan menjadi $\mathrm{CO}_{2}$ dan $\mathrm{H}_{2} \mathrm{O}$ (Sigit, 2006). Dalam proses biodegradasi yang berlangsung, mikroba juga akan mengasimilasi nitrogen, fosfor, kalium dan belerang yang terikat dalam protoplasma sel.

Pada waktu bakteri tumbuh dan berkembang dalam limbah tersebut, karbon akan digunakan untuk menyusun bahan sel penyusun mikroba dengan cara membebaskan karbondioksida dan bahanbahan lain yang mudah menguap. Dalam proses biodegradasi yang berlangsung tersebut, maka mikroba juga akan mengasimilasi nitrogen, fosfor, kalium dan belerang yang terikat dalam protoplasma sel. Hal ini sesuai dengan pernyataan Tjondronegoro (1997 dalam Lestari, 2011), bahwa tujuan utama penanganan limbah secara biologi adalah untuk mendegradasi dengan cara mengoksidasi limbah organik, sehingga senyawa-senyawa kompleks dapat terurai menjadi senyawasenyawa yang lebih sederhana dan 
lebih mudah larut, disamping itu juga dapat dimanfaatkan sebagai nutrisi oleh bakteri indigen.

Sumiarsih (2003 dalam

Sutanto, 2010) menyatakan bahwa eksoenzim (enzim ekstraseluler), yaitu enzim yang bekerjanya di luar sel, umumnya berfungsi untuk "mencernakan" substrat secara hidrolisis, sehingga dapat mengubahnya menjadi molekul yang lebih sederhana dengan Berat Molekul (BM) yang lebih rendah, sehingga dapat masuk melewati membran sel.

Biodegradasi akan memaksimalkan proses penguraian zat organik sehingga mengakibatkan penurunan kadar BOD, dikarenakan degradasi lemak terus berjalan, sehingga kadar lemak akan semakin menurun. Dengan menurunnya kadar lemak, maka jumlah oksigen yang dikonsumsi mikroba dalam proses penguraian akan semakin menurun.

COD merupakan jumlah oksigen kimiawi (mg/L) yang dibutuhkan untuk mengoksidasi bahan organik pada air limbah. COD ini digunakan sebagai ukuran pencemaran limbah oleh zat organik yang secara alamiah dapat dioksidasi melalui suatu proses biologi (biodegradasi) dan mengakibatkan berkurangnya oksigen terlarut dalam limbah. Dengan penurunan lemak akibat biodegradasi, maka kadar lemak akan berkurang dan hal ini akan berakibat pada penurunan jumlah oksigen kimiawi yang dibutuhan mikroba, sehingga kadar COD menjadi berkurang.

TSS merupakan banyaknya kandungan zat padat yang berukuran partikel-partikel halus yang dapat berupa bahan organik maupun bahan non organik. Bahan organik yang melayang-layang akan terdegradasi, sehingga kadar TSS akan menjadi berkurang. Penurunan kadar BOD, COD dan TSS akan memperbaiki kondisi lingkungan perairan sehingga membuat kadar oksigen terlarut (DO) menjadi meningkat.

\section{Identifikasi Bakteri yang Berpotensi dalam Biodegradasi}

Sebelum pelaksanaan identifikasi, terlebih dahulu ketiga isolat paling berpotensi dalam degradasi lemak diamati dan dideskripsikan ciri-ciri makroskopis dan mikroskopisnya. Deskripsi ciri-ciri makroskopis koloni bakteri meliputi bentuk koloni, warna koloni, tepi koloni, elevasi koloni, mengkilat atau suramnya koloni, diameter koloni, tipe pertumbuhan pada medium miring dan kepekatan koloni. Sedangkan deskripsi ciri-ciri mikroskopis meliputi ciri sitologi dan fisiologi. Adapun ciri-ciri sitologi meliputi sifat Gram, bentuk sel, dan ukuran sel, sedangkan ciri fisiologi menggunakan MicrobactTM GNB $12 A / B / E, 24$ E Identification Kits.

Karakterisasi spesies-spesies yang ditemukan disajikan dalam penjabaran berikut:

a. Spesies Staphylococcus aureus

Berdasarkan hasil pengamatan karakteristik ciri morfologi, spesies ini mempunyai warna koloni kuning orange dan berbentuk bundar.Warna koloni $S$. aureus bervariasi antara lain putih, kuning, atau kuning orange (Cream).Selberbentuk kokus dengan ukuran diameter 0,5- 1,5 $\mu \mathrm{m}$, memiliki sifat Gram positif, dan termasuk bakteri aerob. Suhu optimum untuk pertumbuhanberkisar antara 30$37^{\circ} \mathrm{C}$. Isolat ini bisa ditemukan dari makanan, debu, dan air (Holt, J et al. 2000). 
b. Spesies Pseudomonas pseudomallei Hasil pengamatan dari karakteristik morfologi, sitologi dan fisiologi isolat bakteri ini memiliki sifat Gram negatif dengan bentuk sel basil. Warna koloni putih muda. Suhu optimum untuk pertumbuhan berkisar antara $41^{\circ} \mathrm{C}$ (Holt, J et al. 2000). Spesies ini juga diketahui memiliki jumlah flagella $>1$. Secara spesifik, spesies ini memiliki kemampuan dalam mendegradasi bahan organik selain asam organik, dan hal ini dapat ditunjukkan dengan kemampuan degradasi kadar BOD yang cukup signifikan. c. Spesies Actinobacillus sp.

Hasil pengamatan dari karakteristik morfologis, sitologi dan fisiologi bakteri ini memiliki Gram negatif dengan bentuk sel basil. Warna koloni kuning muda. Genus Actinobacillus memiliki bentuk sel oval, spherical atau rod-shape, dengan kisaran ukuran 0.4 x $1.0 \mu \mathrm{m}$. Kebanyakan sel merupakan basil tetapi diselingi dengan adanya unsurunsur kokus yang memberikan karakteristik seperti bentuk kode morse (Holt, J et al. 2000). Spesies ini dapat bersifat parasit atau komensal pada manusia, domba, kuda, babi, berbagai mamalia dan burung (Holt, J et al. 2000).

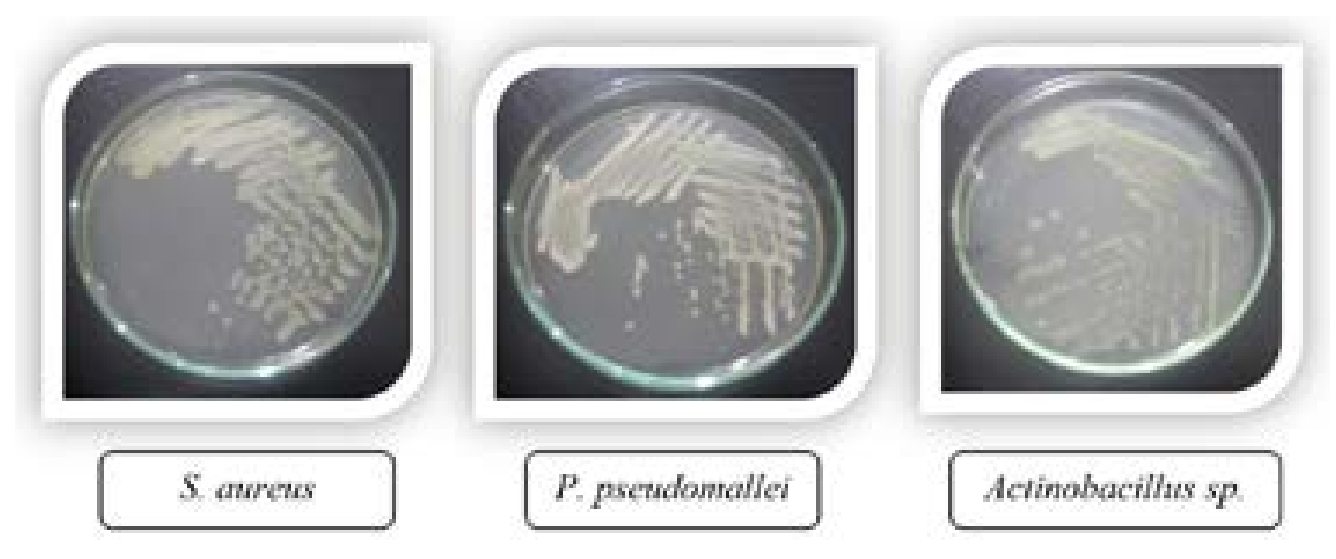

Gambar 1. Isolat Bakteri pada Medium Lempeng

\section{SIMPULAN, SARAN, DAN \\ REKOMENDASI}

1. Dari penelitian biodegradasi secara in vitro, diperoleh spesies-spesies bakteri potensial yang memiliki kemampuan dalam mendegradasi limbah cair pabrik kulit yaitu Staphyllococcus aureus, Pseudomonas pseudomallei, dan Actinobacillus sp.

2. Konsorsium ketiga spesies bakteri indigen terpilih memiliki potensi biodegradasi secara in vitroberdasarkan efisiensi rerata penurunan lemak sebesar $98.42 \%$, TSS sebesar $73.33 \%$, BOD sebesar $35.45 \%$, COD sebesar $69.61 \%$ dan kenaikan kadar oksigen terlarut dalam air dalam kurun waktu 7 hari.

\section{DAFTAR PUSTAKA}

Alexander, M. 1997. Biodegradation and Bioremediation: Second Edition. Department of Soil, Crop, and Atmospheric Sciences, College of Agriculture and Life Science, Cornell University, Ithaca, New York. New York: Academic Press

Atlas, R.M \& Bartha, R. 1998. Microbia 
Ecology, Fundamental and Application. New York: The Benjamin Cummings Publishing Company.

Beishir, L. 1991. Microbiology in Practice. Fifth Eition. New York: harper Collins Publisher Inc.

Burlage, R.S; Atlas, R.; Stahl, D.; Geesey, G.; Sayler, G. 1998. Techniques in Microbial Ecology. New York: Oxford University Press.

Cesaro, A.; Vincenzo, N.; Vicenzo, B. 2013. Wastewater Treatment by Combination of Advanced Oxidation Processes and Conventional Biological Systems. Journal Bioremediation $\mathcal{E}$ Biodegradation 2013 Volume 4, Issue 8.

Fogarty, W.M. 1983. Microbial Enzymes and Biotechnology. London and New York: Applied Science Publisher.

Holt, J.G.; Krieg, N.R.; Sneath, P.H.A.; Staley, J.T.; dan William, S.T. 2000. Bergey's Manual of Determinative Bacteriology 10 ${ }^{\text {th }}$ Edition. New York: Williams and Wilkins Company.

Kawashima, T. 2003. Teknologi Pengolahan Limbah Cair dengan Sistem Lumpur Aktif: Pengetahuan Dasar, Rancangan dan Konstruksi, Pengoperasian Model Pengolahan Limbah Cair Pabrik Karet. Jakarta: JETRO (Japan External Trade Organization).

Keputusan Menteri Lingungan Hidup No. 51 Tahun 1995 tentang Baku Mutu Limbah Cair bagi Kegiatan Industri.

Naisbitt, J. \& Aburdene, P. 1990. Megatrend 2000. London: Sidwick \& Jackson.
Neilson, A.H. \& Allard, A.S. 2009. Chemistry of Organic Pollutant. Journal Environment and Ecological Chemistry Volume 1. Stockholm: Sweddish Environment Research Institute, Ltd.

Ramakrisnan. 2013. Fuelling the Microorganisms for Remediation. Journal Bioremediation \& Biodegradation 2013 Volume 4, Issue 8.

Rozaq, A. 2002. Pengaruh Salinitas terhadap Biodegradsi Cemaran Zat Organik. Jurnal Oseana, Volume XXVII, Nomor 3, tahun 2002: 29-35. http:// www.oseanografi.lipi.go.id, (Online), Diakses 9 Januari 2014.

Suarsini, E. 2007. Bioremediasi Limbah Cair Rumah Tangga menggunakan Konsorsium Bakteri Indigen dalam Menunjang Pembelajaran Masyarakat. Malang: Pascasarjana Universitas Negeri Malang. Disertasi (Tidak Diterbitkan).

Shovitri, M.; Kuswytasari, N.D.; Paramita, P. 2012. Biodegrasi Limbah Organik Pasar dengan Menggunakan Mikroorganisme Alami Tangi Septik. Jurnal Sains dan Seni ITS Vol. 1, Sept. 2012. ISSN: 2301-928X.

Tong Y.; Miao, Y. and Ulrich, A. 2012. Biodegradation of Organic Compounds in OSPW with Microbial Communities Indigenous to MFT. Department of Civil and Environmental Engineering: University of Alberta.

Tsan, H.C. Tanpa Tahun. Microbial Metabolism Biodegradation of Organic Compounds. 